\title{
Die NG Kerk en Gereformeerdheid: Gestalte en uitdagings'
}

C J Wethmar

(Universiteit van Pretoria)

\section{ABSTRACT}

The Dutch Reformed Church and the Reformed tradition: expression and challenges

In this article a brief analysis is presented of the manner in which the Reformed tradition finds expression in die Dutch Reformed Church in South Africa. Such an analysis presupposes answers to the questions why' such an attempt is necessary and what the identity of the Reformed tradition is. These answers are suggested in the first two sections of the article. The third section contains the envisaged outline of the manner in which the Dutch Reformed Church represents the Reformed tradition. This leads to the conclusion that the contribution which this church could strive to make to the church scene in South Africa is to promote the combination of the faith dimensions of knowledge, experience and obedience which is characteristic of the Reformed tradition.

\section{WAAROM DIE HUIDIGE VRAAG NA GEREFORMEERDE IDENTITEIT?}

Die taak wat in hierdie bydrae hanteer word, is om ' $n$ kort aanduiding te gec van die gestalte wat die Gereformecrde tradisie in die NG Kerk aanneem en van die uitdagings wat die tockoms daarvoor inhou. Dat dic NG Kerk ' $n$ Gereformeerde kerk is en wil wees, blyk nie alleen uit sy naam nie, maar ook uit die cerste artikel van sy kerkorde wat bepaal dat die leer van hierdie kerk uitdrukking vind in die drie bekende Reformatoriese formuliere van enigheid (Coertzen 1994:1). Tog kan enige icmand waarneem dat, soos dit in ander Reformatoriese kerke die geval is, ook in die NG Kerk hierdie Gereformeerde identiteit nie "n onomstrede saak is nie. Behalwe uit die daaglikse praktyk in baie gemeentes, word dit ook duidelik uit die titels van ' $n$ hele aantal boeke uit die afgelope tyd waarvan lidmate van die NG Kerk outeurs of mede-outeurs is. Titels soos "Is die NG Kerk nog die NG Kerk" (Snyman 1998) of "Vraagtekens oor Gereformeerdheid" (Boesak en Fourie 1998) of "Nuut gedink oor ons Gereformeerde tradisie" (Burger 200I) gee 'n aanduiding

1 Hierdie bydrae was oorspronklik gelewer as " $n$ kort inleiding by " $n$ simposium oor die tema 350 jaar Gereformeerd: Gestaltes en Uitdagings wat op 22 April 2002 plaasgevind het by die Universiteit van Pretoria. 
daarvan dat die Gereformeerde identiteit ook in die NG Kerk nie ' $n$ vanselfsprekendheid is nie maar telkens opnuut weer verwerf en bevestig moet word. Dat dit die geval is, hang enersyds met die eie aard van Gereformeerdheid saam en andersyds daarmee dat die drie honderd en vyftig jaar wat ons vanjaar in Suid-Afrika so ywerig vier ' $n$ gegewe is wat groot uitdagings vir ons Gereformeerdheid inhou. Sedert die Gereformeerde tradisie drie honderd en vyftig jaar gelede in Suid-Afrika voet aan wal gesit het, moes dit oor gevaarlike berge en afskuwelike afgronde van die geskiedenis trek om by ons uit te kom. In hierdie proses was die Gereformeerde geloof blootgestel aan die gevaar van verintellektualisering in die na-reformatoriese ortodoksie van die sewentiende eeu; aan die gevaar van veremosionalisering in die Piëtisme van die agtiende eeu en aan die gevaar van die verjuridisering van die konfessionalisme wat in die negentiende eeu in verskillende kerklike kringe ontwikkel het, om uiteindelik ook nog te staan te kom voor die bedreiging van 'n radikale reduksic in die modernismc en postmodernisme.

Die invloed van die modernisme waarna pas verwys is, was in Europa tot en met die tweede wêreldoorlog in ' $n$ groot mate tot intellektuele kringe beperk maar het sedertdien soos ' $n$ vloedgolf oor breë lae van die bevolking gespoel met al die kerklik verwerende gevolge daarvan (Graafland 1973:15). Wat Suid-Afrika betref, sou ' $n$ mens kon sê, dat dit ' $n$ proses is wat sedert die politieke herskikking van die negentiger jare van die twintigste eeu sy volle intensiteit bereik het.

Dit is dus nie so vreemd dat die afgelope tyd so dikwels na die Gereformeerde identiteit gevra word nie. Dit is ' $n$ vraag wat deur historiese faktore genoodsaak word maar dit is ook ' $n$ vraag wat inherent met Gereformeerd-wees gegee is. Gereformeerd-wees is nooit ' $n$ status quo nie, maar ' $\mathrm{n}$ beweging om steeds meer te konformeer aan die beloftes en eise van Gods Woord. Gereformeerd-wees bestaan slegs as Gereformeerd-word (Graafland 1973:18).

Die implikasie hiervan is ook dat daar nie slegs een gestalte van Gereformeerd-wees is nie maar dat in verskillende omstandighede verskillende variante van Gereformeerd-wees na vore tree. Maar tog is daar ook so-iets soos dit wat die Nederlanders die Gereformeerde gezindte noem. Dit is ' $n$ algemene Gereformeerd-wees wat oor kerkgrense heen gestalte kry. Voordat ek 'n paar opmerkings mak oor spesifieke uitdagings wat Gereformeerd-wees tans in die NG Kerk beleef, moet ek eers in die algemeen probeer identifiseer wat dit is wat ' $n$ bepaalde geloofstyl Gereformeerd maak.

\section{WAT IS GEREFORMEERDE IDENTITEIT?}

Meestal word by die beskrywing van so ' $n$ algemene Gereformeerdheid die uitgangspunt geneem by die bekende eksklusiwiteitsuitsprake van dic 
Reformasie waarvolgens ' $n$ mens deur die Skrif alleen, deur die geloof alleen en deur die genade alleen deel kry aan die heil. Ek wil hierby aansluit maar dan op so ' $n$ wyse dat twee sake beklemtoon word. Die eerste is dat hierdie drie eksklusiwiteitsuitsprake alleen reg verstaan word as hulle ten nouste met mekaar verbind word. En die tweede is dat om hulle volle diepte te verstaan ' $n$ mens hulle moet sien teen die agtergrond van ' $n$ fundamentele herstel wat in die Reformasietyd ten opsigte van die openbaringsbegrip tot stand gekom het.

Sedert die Aleksandrynse teologie van Origenes en Clemens in die derde ecu het die gedagte ontwikkel dat die Bybel ' $n$ duister bock is wat alleen deur die kerklike leeramp uitgelê kan word (Rossouw 1963:64). Die redding was nie soseer te vind in " $n$ persoonlike verhouding met God nie, maar hoofsaaklik deur deelname aan die sakramente wat die kerk beskikbaar stel aan diegene wat aan die kerk gehoorsaam is. Die genade word hier tot 'n fisiese werklikheid waaraan 'n mens deur die sakramente deelkry terwyl die geloof tot gehoorsaamheid gereduseer word.

Hierteenoor het die Reformasie beklemtoon dat die Bybel 'n duidelike boek is, duidelik nic in die eerste instansie op ' $n$ scmantiese vlak nie maar op ' $n$ religicuse en geloofsvlak (Rossouw 1963:164). Die Bybel is sy eie uitlegger. Sacra scriptura sui ipsius interpres het die Reformatore gesê (Berkouwer 1966:180). Daarmee het hulle bedoel dat die Heilige Gees wat die primêre outeur van die Heilige Skrif is in die mens die geloof in die sentrale heilsboodskap van die Skrif tot stand bring. So kom ' $n$ mens in ' $n$ persoonlike verhouding tot God tereg waarin heil ervaar word.

n ' $n$ Reformatoriese kerk speel die Heilige Skrif ' $n$ fundamentele rol omdat die prediking van die evangelic dic wyse is waarop God met die mens praat. In die wyse waarop God deur die Skrifboodskap die mens aanspreek, het die Reformatore drie dimensies ontdek wat onderskeidelik dic waarheidsdimensie, die beloftedimensie en die vervullingsdimensie genoem kan word (Rossouw 1963:166). Met hierdic terme word agtereenvolgens die volgende bedoel: in die proses waarin deur die verkondiging van dic Skrifboodskap die heil tot stand kom, word daar getuig daaroor dat ons redding buite onsself (extra nos) in die Persoon en werk van Jesus Christus geleë is - dit is die waarheidsdimensie in die verkondiging van die Skrifboodskap. Maar die heil geskied nic alleen buite ons in Christus nie. Hierdie heilsboodskap word deur die Skrif as belofte aan ons betuig en verkondig. Die heil geskied in Christus nie alleen buite ons nie, maar ook vir ons (pro nobis) - dit is dic beloftedimensie van die Skrifboodskap. En dic cvangelie as heilsboodskap vir ons word deur die Heilige Gees in ons lewens (in nobis) toegepas sodat ons in gehoorsaamheid daaraan lewe (Krusche 1957:294). Dic heilsgebeure, soos die Reformasie dit sien, verwys dus nie alleen na Christus 
buite ons en die belofte van die evangelie vir ons nie maar ook na die totstandkoming van die geloof in ons. Dit is die vervullingsdimensie in die geskied van Gods Woord. Die Reformatore het in hierdie verband gepraat van die testimonium Spiritus Sancti internum, die inwendige getuienis van die Heilige Gees (Rossouw 1963: 236). Wanneer dic Reformasic dus sola Scriptura sê, gaan dit nie maar net om die Bybel as boek nie, maar om ' $n$ omvattende heilsgebeure.

In die lig hiervan moct ons ook verstaan dat wanneer die Reformasie sê dat die heil sola fide, deur die geloof alleen, tot stand kom daarmee nie maar net op ' $n$ vae gemoedsaandoening gedui word nie. Dit is cerder so dat in ooreenstemming met en in aansluiting by die drie elemente wat in die verkondiging van die Skrifboodskap ontdek is, die Reformatore ook in die geloof drie elemente aangedui het tewete kennis, vertroue en gehoorsaamheid. Die geloof is kennend gerig op die heilsgebeure in Christus, ervaar met vertroue die toesegging van die heil en leef in dic krag van die Gees ' $n$ lewe van tocwyding en gehoorsaamheid aan Christus.

Waar die redding van ' $\mathrm{n}$ mens se lewe deur die Skrif alleen en deur die geloof alleen op hierdie manier gesien word, word dit ook duidelik waarom Gereformeerdes altyd daar byvoeg dat dit alles uit genade geskied. Daarmee word bedoel dat die geloof nie ' $n$ menslike prestasie of ' $n$ verdienstelike werk is nic. Ons verlorenheid is so groot dat ons niks het om aan te bied nie. Daarom is die geloof soos ' $n$ leë hand waarmee ons dit ontvang wat God verniet gee (Jonker 1996). Die geloof is die weg waarlangs ons Gods genade ontvang. En dit is juis om hierdie genadekarakter van die geloof te beklemtoon dat Gereformeerdes soveel klem op dic uitverkiesing gelê het. Daarmec wou hulle sê dat die inisiatief vir ons redding radikaal by God is.

Die stelling is reeds gemaak dat die geloof ook gehoorsaamheid behels. Dit hang saam daarmee dat Gereformeerdes daarvan oortuig is dat die mens wat uit genade gered is; ook persoonlik deur die Gees geheilig word en in die wêreld uitgestuur word om daar die wil van God te doen (Jonker 1996). Die heiliging van die lewe speel nie net in die persoonlike sfeer af nie. Gereformecrdes streef daarna dat Gods eer op alle terreine van die lewe gedien word. Dit is tipies Gereformeerd om die wet van God in alle lewensfere te wil gehoorsaam. Daarmee is dus gesê dat die Gereformeerde ethos daardeur gekenmerk word dat die wet van God ' $n$ belangrike rol in die lewe speel. Anders as in die geval van die Lutherane waar die wet agter die evangelie verdwyn, ken die Gereformeerde lewenstyl aan die wet 'n belangrike plek toe. Die wet dien as die struktuur van " $n$ geheiligde lewe.

' $n$ Beskrywing van Gereformeerdhcid sou onvolledig wees as daar nic ook na dic verbond verwys word nie. Vir Gereformeerdes is die 
geloof nie net ' $n$ saak van die individu nie, maar dit word ook beleef in die opvolging van geslagte. Toe die Anabaptiste radikaal met die kerklike tradisie breek en die kern van die geloof gaan vind in die strewe na buitengewone geestelike gawes en die gecsdriftige Christendom van 1 Korinthe 14 as model vir die ware kerk invoer, het hulle ook die kinderdoop verwerp (Jonker 1998:41). Hiermee kon die Reformatore nic akkoord gaan nie en daarmee was hulle voor die taak gestel om die regmatigheid van die kinderdoop te bevestig. Dit het hulle gedoen deur die kinderdoop in die verbondsbegrip te begrond (Jonker 1996). Die kinderdoop is gesien in die lig van die besnydenis en dus as teken en seël van die verbond van Gods genade met sy volk. Die geloof is nic alleen ' $n$ saak vir die individu nic, maar vir opeenvolgende geslagte en trouens vir die hele samelewing (Jonker 1996).

\section{DIE GEREFORMEERDE IDENTITEIT IN DIE NG KERK}

Die basiese elemente van die Reformatoriese ideaal kan dus beskryf word met die kernwoorde Skrif, geloof, genade, wet en verbond. Ons het vroeër gesien dat hierdie ideaal nooit ' $n$ vanselfsprekendheid kan wees nie maar altyd ' $n$ sekere worsteling vereis. Ten slotte kan ' $n$ paar opmerkinge gemaak word oor hoe daar in die verlede in die NG Kerk om hierdie idcaal geworstel is en watter uitdagings die toekoms in hierdie verband stel.

Soos in ander kerke die geval was, het dit ook in dic NG Kerk geblyk dat die Reformatoriese klem op Skrifgebruik op verskillende maniere kan ontspoor. Een so ' $n$ manier kom voor wanneer fundamentalisties met die Skrif omgegaan word. Dit lei daartoe dat op ' $n$ hermeneutiese wyse met die Skrif gewerk word wat nie werklik met die eie aard van die Skrif ooreenstem nie (Jonker 1998:45). Dit kan daartoe lei dat die Skrif wetties en onhistories gelees word om allerlei sake te legitimeer wat werklik nie met die grondmotiewe van die Skrif ooreenstem nie. " Ander manier waarop die klem op die gebruik van die Skrif ontspoor, word aangetref wanneer ' $n$ verabsolutering van die Aufklärungshermeneutiek lei tot ' $n$ geradikaliseerde historiese kritiek wat eweneens nic laat reg geskied aan die eie aard van die Skrif nie. Dit lei dan tot ' $n$ eksistensiale of ' $n$ sosiale interpretasie waarin dit nie meer gaan om Gods Woord in mensetaal nie maar eerder om mensetaal in die plek van Gods Woord. Ook die NG Kerk ken die worsteling tussen hierdie uiterstes. Daarom moes die Algemene Sinode van 1986 ' $n$ uitvoerige verklaring oor die Skrifgesag formuleer en daarom gaan die Algemene Sinode later vanjaar weer intensief met die Skrifvraagstuk besig wees. As die Skrifgesag in die gedrang kom, kom die Reformatoriese aard van die kerk in gedrang. Waar die vertroue in die Bybel as Gods lewende Woord ondermyn word, word ook 'n skadu gewerp oor die God van dic Woord 
omdat Hy dan nie meer ontmoet word as die lewende God wat in ons wêreld en geskiedenis teenwoordig is nie (Smit 1998:36).

' $n$ Laaste voorbeeld van ' $n$ terrein waarop daar in die NG Kerk geworstel word om 'n verantwoorde toe-eiening van die Gereformeerde tradisic is die verhouding tussen wat ' $n$ mens sou kon noem die subjekticwe en objektiewe faset van die heil. Vir ' $n$ geruime tyd reeds is daar diegene in die NG Kerk wat die verbondsbegrip op so " $n$ wyse hanteer dat die heil ' $n$ objektiewe gegewe word wat byna as " $n$ outomatiese vanselfsprekendheid beskou word wat so deur God tot stand gebring word dat die mens eintlik nie daarby betrokke is nie. Daarteenoor staan die standpunt van diegene wat deur heiligheidsbewegings uit die verlede en deur Charismatiese invloede uit die hede beweeg word om groot klem te lê op die menslike aktiwiteit, ervaring en verantwoordelikheid by dic tot stand koming van die heil. Die stryd tussen hierdie twee benaderings het hom op vele terreine van die kerklike lewe en besinning laat geld sodat die NG Kerk se Algemene Sinode van 1990 verplig was om ' $n$ formulering te probeer vind wat ' $n$ Bybelse en Reformatoriese balans oor hicrdie aangeleentheid kan bied: Die geloof is Gods werk, maar dan so dat dit nie aan die menslike subjektiwiteit verbygaan nie (NG Kerk 1990:116-118).

\section{GEVOLGTREKKING}

In die intra-reformatoriese gesprek in Suid-Afrika gebeur dit nogal by geleentheid dat die NG Kerk piëtisme en wettisisme ten laste gelê word. Tog sou ' $n$ mens die vraag kon stel of die bydrae wat die NG Kerk nie alleen tot die gemeenskap van Reformatoriese kerke in Suid-Afrika nie, maar ook tot die breëre spektrum van Christelike kerke in ons land kan mak nie sou kon bestaan in die beklemtoning daarvan dat ' $n$ balans gevind moet word tussen die geloofselemente van kennis, ervaring en gehoorsaamheid nie - al moet ons saam met Paulus sê: dit is nie asof ons dic docl al bereik het nie, maar ons span ons in om dit te verkry (Fil 3:12). Langs hierdie weg kan die gevare van verintellektualisering, veremosionalisering en verjuridisering wat die kerk die afgelope drie honderd en vyftig jaar telkens bedreig het, oorleef word.

\section{Literatuurverwysings}

Berkouwer, G C 1966. De Heilige Schrift I, Kampen: Kok.

Boesak, W A en Fourie, 'J J A (reds) 1998. Vraagickens oor Gereformeerdheid. Belhar: LUS Uitgewers.

Burger, C 2001. Ons weet aan wie ons behoort. Nuut nagedink oor ons gereformeerde tradisie. Wellington: Lux Verbi.

Coertzen, P 1994. Die Kerkorde van die Nederduitse Gereformeerde Kerk. Wellington: Hugenote-Uitgewers.

Graafland. C 1973. Waurom nog gereformeerd? Kampen: Kok. 
Jonker, W D 1989. Die eie-aard van die gereformeerde spiritualitcit. Ned Geref Teologiese Ty'dskrif 30(3):288-299.

-, W D Wat maak ons gereformeerd? Die Kerkbode 7 Junie 1996.

-, W D 1998. Sterk- en swakpunte van die gereformeerde spiritualitcit? in: Boesak, W A en Fourie, P J A (reds) 1998. Vraagtekens oor Gereformeerdheid. Belhar: LUS Uitgewers, 38-48.

Krusche, W 1957. Das Wirken des Heiligen Geistes nach Calvin. Göttingen: Vandenhoeck und Ruprecht.

Ned Geref Kerk, 1990: Gods werk of mensewerk? In: Agenda van die Algemene Sinode, 116-118.

Rossouw, H W 1963. Klaarheid en Interpretasie. Enkele probleemhistoriese gesigspunte in verband met die leer van die duidelikheid van die Heilige Skrif. Amsterdam: Jacob van Campen.

Smit, D J 1998. Wat beteken 'Gereformeerd'? in: Boesak, W A en Fourie, P J A (reds). Vraagtekens oor Gereformeerdheid. Belhar: LUS Uitgewers, 20-37.

Snyman, F (red) 1998. Is die NG Kerk nog die NG Kerk? Antwoorde op die identiteitskrisis in die kerk. Wellington: Hugenotc-Uitgewers. 